DOI https://doi.org/10.30525/978-9934-26-004-9-87

\title{
SUBSTANTIATION OF PEDAGOGICAL CONDITIONS OF SOUND ENGINEERING TRAINING OF STUDENTS OF HIGHER EDUCATION INSTITUTIONS OF SPECIALTY 025 MUSICAL ART
}

\author{
Koriakin O. O. \\ Candidate of Pedagogical Sciences, \\ Senior Lecturer at the Department of Choral Conducting, \\ Vocal and Methods of Music Education \\ Sumy State Pedagogical University named after A. S. Makarenko \\ Sumy, Ukraine
}

In modern socio-cultural conditions, the requirements for specialists are significantly increasing, who in the rapidly changing world and the deepening of its globalization must be able to creatively solve various professional problems, demonstrate readiness for innovation and in the profession innovation activity.

Modern institutions in the sphere of culture and art are interested in competitive professionals with a well-established system of competencies that meet modern requirements for professional activity.

An important component of professional training of specialists in the specialty 025 Musical art is sound engineering training as an indicator of the appropriate level of professionalism. This actualizes the aspect of training higher education students in this specialty, who have mastered the basics of sound engineering and are able to apply these competencies in professional activities.

Problems of musical acoustics and physics of sound were covered in the works of such authors as: M. Barron [1], R. Berg, D. Stork [2], F. Toole [5] and others, various aspects of sound engineering were covered in the works of such authors as: A. Farnell [3], D. Gibson [4] and others. However, the pedagogical conditions of sound engineering training have not been the subject of any of the relevant studies.

The outlined problem actualizes updating of the maintenance, forms and methods of professional training of specialists on a specialty 025 Musical art of establishments of higher education, in particular, in Ukraine, and also definition of pedagogical conditions of sound engineering training of higher education students. 
Sound engineering training of higher education students in the specialty 025 Musical art will be effective if the pedagogical conditions are met: 1) purposeful professional development of higher education students by means of sound engineering; 2) mastering by the subjects of the educational process of the system of theoretical knowledge on the basics of music acoustics and sound engineering; 3 ) deepening the practical experience of sound engineering in the process of professional training.

The first component of the first pedagogical condition - the organization with the use of sound engineering of various activities with the higher education students. Some scientific works emphasize the increase of motivation for activity after the beginning of this activity and already in the process of its implementation. In terms of professional training of higher education students in the specialty 025 Musical art, the following activities include: 1) career guidance events (career guidance days of the university and structural unit, University days), in which entrants and students take a direct part in the event, which is implemented using the sound-technical complex and means of sound engineering; 2) scientific and practical conferences of different levels (conferences for students of the structural unit, conferences of regional, national and international level).

The second component of the first pedagogical condition is the organization of educational activities in institutions whose activities are related to sound engineering. Educational activity is an important component of the university and is aimed, in particular, at promoting and promoting the achievements of music culture (which is also emphasized in the content of professional competencies defined by the standard of higher education of the first (bachelor) level of higher education in the specialty 025 Musical Arts).

Such measures that can be implemented in the process of professional training of higher education students in the specialty 025 Musical Arts include: 1) excursions to the regional philharmonic, theater, palaces of culture, which have a modern musical and technical complex and sound equipment and in which highly qualified specialists work as sound engineers; 2) excursions to recording studios, which are equipped and appropriately prepared sound rooms and control rooms, as well as staff with appropriate professional qualifications.

The second pedagogical condition - the assimilation of the subjects of the educational process of the system of theoretical knowledge on the basics of music acoustics and sound engineering is realized in two components.

The first component of the second pedagogical condition is the inclusion in the disciplines of the cycle of professional training of elements related to music acoustics and sound engineering, which stimulate the development of interdisciplinary links. The importance of systematization in the educational process is emphasized in many scientific studies, at the same time the methodological significance of interdisciplinary links is substantiated by 76 
researchers of the higher education system. The disciplines of the cycle of professional training of music-theoretical direction, as well as professional disciplines may include topics related to the nature of sound, the history of sound engineering, sound technology, the use of sound engineering in performance and more.

The second component of the second pedagogical condition is the mastering by the scientific and pedagogical workers of the system of basic sound engineering competencies. It is obvious that in order to provide sound engineering training for applicants for higher education in the specialty 025 Music Art, such training should be given to representatives of the teaching staff who provide the educational process in this specialty, not only those who teach sound engineering disciplines. Such training can be realized by obtaining appropriate qualifications by scientific and pedagogical workers within educational and professional programs in higher education institutions at the second (master's) level, passing of advanced training courses in sound engineering orientation by scientific and pedagogical workers, as well as attending master classes, webinars, round tables and other professional development activities that allow to master the basics of the system of basic sound engineering competencies.

The third component of the second pedagogical condition is the integration into the curriculum and educational-professional program of the educational components «Fundamentals of Music Acoustics» [2] and «Fundamentals of Sound Engineering» [3]. In the system of professional training, in particular, in the specialty 025 Musical art, mastering competencies and achieving learning outcomes is provided within the educational components, respectively, in order to provide sound engineering training is necessary to introduce into the educational process such disciplines, mastering which will allow higher education competencies and learning outcomes. Such disciplines that provide the relevant components of sound engineering training are «Fundamentals of Music Acoustics» and «Fundamentals of Sound Engineering».

The third pedagogical condition - deepening the practical experience of sound engineering in the process of professional training is realized in three components.

The first component of the third pedagogical condition is the deepening of practical sound engineering training in the content of industrial practice. An important component of professional training of higher education students in the specialty 025 Musical art is practical training, which, in particular, is carried out in the process of various types of practice. The content of the production practice provides in the maximum approximation to the content of the relevant job descriptions to perform the duties of the artist-performer. It is obvious that in the process of rehearsal work and preparation of a concert number, trainees - future artists have the opportunity to consolidate in practice 
the acquired sound engineering competencies. In addition, the music and technical complex of the institution - the base of practice and the specialist sound engineer in a systematic interaction with the trainees are able to form in them additional positive practical experience of sound engineering.

The second component of the third pedagogical condition is the organization of festivals and competitions at the level of higher education institutions, the performance of which is associated with the practical application of sound engineering competencies. Researchers emphasize the need for future artists-performers in competitive events of different levels in order to develop performance reliability, expand concert-performing experience, etc., at the same time, participation in such events also deepens sound engineering experience in the use of musical equipment in the preparation performance of musical works.

The third component of the third pedagogical condition - integration into the curriculum and educational-professional program of educational components «Fundamentals of Music Acoustics» and «Fundamentals of Sound Engineering» is integrative for the second and third pedagogical conditions. Providing practical experience in the field of sound engineering is possible in the content of educational components, mastering which will allow higher education students to acquire relevant professional competencies and learning outcomes, and consolidate them in practice. The practical experience of sound engineering is provided by the discipline «Fundamentals of Sound Engineering», as well as the passage of industrial practice.

Pedagogical conditions of sound engineering training of students of higher education institutions of specialty 025 Musical art can be realized on condition of observance of cognitive, activity and personality-oriented approaches in the educational process, which are not the subject of these theses.

\section{References:}

1. Barron M. Auditorium Acoustics and Architectural Design. Second Edition. Spon Press, London and New York, 2010. 481 p.

2. Berg R.E., Stork D.G. The physics of sound. San Francisco: Pearson Education, Inc., 2005. 399 p.

3. Farnell A. Designing sound. Cambridge-London: The MIT Press, 2010. $664 \mathrm{p}$.

4. Gibson D. The Art of Mixing: A Visual Guide to Recording, Engineering and Production. CA., 2005. 129 p.

5. Toole F. Sound Reproduction: The Acoustics and Psychoacoustics of Loudspeakers and Rooms. New York-London, 2013. 550 p. 